\title{
Short term effects of a low-carbohydrate diet in overweight and obese subjects with low HDL-C levels
}

\author{
Ahmet Selçuk Can $^{1 *}$, Canan Uysal ${ }^{2}$ K Erhan Palaoğlu ${ }^{3}$
}

\begin{abstract}
Background: The aim of this study was to evaluate short-term effects of a low-carbohydrate diet in overweight and obese subjects with low HDL-C levels.

Methods: Overweight (BMI between $25-30 \mathrm{~kg} / \mathrm{m}^{2}$ ) or obese (BMI over $30 \mathrm{~kg} / \mathrm{m}^{2}$ ) subjects with low HDL-C levels (men with $\mathrm{HDL}-\mathrm{C}<1.03$, women $<1.29 \mathrm{mmol} / \mathrm{l}$ ) were invited to the study. A $1400 \mathrm{kcal} 75$-gram carbohydrate $(\mathrm{CHO})$ diet was given to women and an $1800 \mathrm{kcal}$ 100-gram $\mathrm{CHO}$ diet was given to men for four weeks. The distribution of daily energy of the prescribed diet was $21-22 \%$ from $\mathrm{CHO}, 26-29 \%$ from protein and $49-53 \%$ from fat. Subjects completed a three-day dietary intake record before each visit. Anthropometric indices, body fat ratio, blood lipids, glucose and insulin were measured. Baseline and week-four results were compared with a Wilcoxon signed ranks test.
\end{abstract}

Results: Twenty-five women and 18 men participated. Basal median LDL-C level of men was 3.11 and basal median LDL-C level of women was $3.00 \mathrm{mmol} / \mathrm{l}$. After four weeks of a low-carbohydrate diet, the median energy intake decreased from 1901 to $1307 \mathrm{kcal} /$ day, daily energy from carbohydrate from 55\% to 33\%, body weight from 87.7 to $83.0 \mathrm{~kg}$ and HDL-C increased from 0.83 to $0.96 \mathrm{mmol} / \mathrm{l}$ in men ( $<0.002$, for all). After four weeks of a low-carbohydrate diet, the median energy intake tended to decrease (from 1463 to $1243 \mathrm{kcal}, \mathrm{p}=0.052$ ), daily energy from carbohydrate decreased from $53 \%$ to $30 \%(p<0.001)$ and body weight decreased from 73.2 to 70.8 $\mathrm{kg}(\mathrm{p}<0.001)$ in women, but HDL-C did not significantly change (from 1.03 to $1.01 \mathrm{mmol} / \mathrm{l}, \mathrm{p}=0.165$ ). There were significant decreases in body mass index, waist circumference, body fat ratio, systolic blood pressure, total cholesterol, triglyceride and insulin levels in all subjects.

Conclusions: HDL-C levels increased significantly with energy restriction, carbohydrate restriction and weight loss in men. HDL-C levels didn't change in women in whom there was no significant energy restriction but a significant carbohydrate restriction and a relatively small but significant weight loss. Our results suggest that both energy and carbohydrate restriction should be considered in overweight and obese subjects with low HDL-C levels, especially when LDL-C levels are not elevated.

\section{Background}

A low high density lipoprotein cholesterol (HDL-C) level is an independent risk factor for atherosclerotic cardiovascular disease (CVD) [1]. Even in subjects with a low density lipoprotein cholesterol (LDL-C) level that is below $60 \mathrm{mg} / \mathrm{dl}$, either achieved with lipid lowering agents or occurring spontaneously, HDL-C levels show

\footnotetext{
* Correspondence: selcukcan@endokrinoloji.com

'Department of Medicine, Kadir Has University, Faculty of Medicine, Vefa Bey

Sokak, No: 5, 34349, Gayrettepe, Beșiktaş, Istanbul, Turkey

Full list of author information is available at the end of the article
}

an inverse relationship with CVD risk and a U-shaped relationship with all-cause mortality [2]. The increase in HDL-C level has been found to have a strong independent effect in reducing CVD risk after adjustment of other lipid changes in patients who are on lipid lowering therapy [3]. Although relatively effective LDL-C lowering medical therapies are available, drugs that raise HDL-C level as the principal pharmacodynamic effect do not exist. Physical activity, cessation of smoking, weight loss, moderate alcohol intake, a diet rich in omega-3 polyunsaturated fatty acids and a diet low in carbohydrates are 
HDL-C raising strategies [4]. The Mediterranean diet has beneficial effects on CVD risk [5] and is effective in raising HDL-C levels [6]. A targeted lifestyle change program improves CVD risk factors and the distribution of plasma lipoprotein subclasses, especially small dense LDL-C particles [7]. The United States National Cholesterol Education Program Adult Treatment Panel III (NCEP) recommends therapeutic lifestyle changes diet to reduce the risk of CVD [1]. The distribution of daily energy intake is $50-60 \%$ from carbohydrate, $15 \%$ from protein and $25-35 \%$ from fat in the therapeutic lifestyle changes diet. American Heart Association and World Health Organization also recommend a low-fat diet $[8,9]$. In view of the recent data on the benefits of low-carbohydrate diets, these official recommendations have been challenged [10-12]. The primary objective of the therapeutic lifestyle changes diet is to reduce LDL-C levels to prevent CVD, but low-fat diets decrease HDL-C levels and increase triglycerides as well [13-18]. There are no dietary intervention studies performed in subjects with only low HDL-C levels. The aim of this study was to evaluate the effects of a low-carbohydrate diet in overweight and obese subjects with low HDL-C levels.

\section{Methods}

Subjects were invited to the study from the Turkish Heart Study database. Turkish Heart Study is an epidemiological survey of CVD risk factors periodically performed in Turkey. In 2005 and 2006, we reviewed our 2003 Turkish Heart Study data [19] and invited overweight [body mass index (BMI) $\geq 25$ and $<30 \mathrm{~kg} / \mathrm{m}^{2}$ ] and obese (BMI $\geq 30 \mathrm{~kg} / \mathrm{m}^{2}$ ) subjects with a low HDL-C level. NCEP HDL-C criterion [HDL-C $<50 \mathrm{mg} / \mathrm{dl}$ $(1.29 \mathrm{mmol} / \mathrm{l})$ for women and $<40 \mathrm{mg} / \mathrm{dl}(1.03 \mathrm{mmol} / \mathrm{l})$ for men] was used to categorize subjects to low HDL-C status [1]. The exclusion criteria were the presence of a major medical illness like renal disease, liver disease, cancer, diabetes and CVD and the use of lipid-lowering drugs. A phone call was made to subjects for invitation and to explain the study. Subjects who agreed to participate were instructed on how to record dietary intake and were asked to come to our outpatient offices between $7 \mathrm{am}$ and $10 \mathrm{am}$ after a 10-hour fast. At each visit blood pressure, anthropometric indices and body fat ratio were measured and a fasting blood sample was obtained. The study was approved by the Ethics Committee of Kadir Has University, Faculty of Medicine. All subjects signed written informed consent.

\section{Clinical variables}

Body weight and composition were measured with a Tanita Body Composition Analyzer BC-418 MA (Tanita Corporation, Tokyo, Japan). Bioimpedance analysis was performed in the morning before breakfast and subjects were instructed to void before the measurement. Body weight was measured in kilograms to within $0.1 \mathrm{~kg}$. Height was measured to within $0.5 \mathrm{~cm}$ with a measuring stick. BMI was calculated by dividing the weight in kilograms to squared height in meters. Waist circumference was measured at the midpoint between lower margin of the rib cage and superior iliac crest during mild expiration with a non-elastic measuring tape. Waist circumference was measured to the nearest $0.5 \mathrm{~cm}$. All measurements were taken when subjects were on light clothing and after shoes were taken off. Blood pressure was measured on the right arm with an automated sphygmomanometer (Omron automatic blood pressure monitor with IntelliSense ${ }^{\oplus}$, Bannockburn, IL, USA) after fifteen minute of rest with the subject in the sitting position. The mean of two recordings, five minutes apart was recorded.

The metabolic syndrome was defined by the NCEP criteria that were modified by the American Heart Association and the United States National Heart Lung and Blood Institute $[1,20]$. According to NCEP, metabolic syndrome is diagnosed if three of the following five components are abnormal: 1) waist circumference $\geq 102 \mathrm{~cm}$ in men or $\geq 88 \mathrm{~cm}$ in women, 2) systolic blood pressure $\geq 130 \mathrm{mmHg}$ or diastolic blood pressure $\geq 85 \mathrm{mmHg}, 3$ ) serum triglycerides $\geq 150 \mathrm{mg} / \mathrm{dl}(1.69 \mathrm{mmol} / \mathrm{l}), 4) \mathrm{HDL}-\mathrm{C}<50 \mathrm{mg} / \mathrm{dl}$ $(1.29 \mathrm{mmol} / \mathrm{l})$ for women and $<40 \mathrm{mg} / \mathrm{dl}(1.03 \mathrm{mmol} / \mathrm{l})$ for men [1], 5) fasting plasma glucose $\geq 100 \mathrm{mg} / \mathrm{dl}$ (5.56 mmol/l) [20]. Subjects on drug therapy for hypertension, high blood glucose or abnormal lipid levels are also assigned to abnormal component status [20].

\section{Laboratory variables}

A cobas 6000 multichannel analyzer (Hitachi High Technologies Corporation, Tokyo, Japan) and commercial kits (Roche Diagnostics, Mannheim, Germany) were used for measurement of cholesterol, HDL-C, triglycerides and glucose. Cholesterol (kit: CHOL2) and triglycerides (kit: TRIGL) were measured with an enzymatic colorimetric method. A homogeneous enzymatic colorimetric test was used for direct measurement of HDL-C (kit: HDLC3). LDL cholesterol (LDL-C) was calculated by the Friedewald formula. Glucose (kit: GLUC3) was measured by hexokinase method. Fasting insulin levels were measured with an electrochemiluminescence immunoassay (kit: Insulin) in a cobas e 411 analyzer (Hitachi High Technologies Corporation, Tokyo, Japan). Insulin resistance was estimated by Homeostasis Model Assessment (HOMA) equation. HOMA equals fasting serum insulin $(\mu \mathrm{U} / \mathrm{ml})$ times fasting plasma glucose (mmol/l) divided by 22.5 [21].

\section{Dietary intervention}

The participants were free-living and were instructed not to alter their physical activity level during the study. 
Subjects visited Medical Nutrition Center three times: basal, at two weeks and at four weeks. The results of baseline and week-four visits are reported here. Subjects were asked to complete a three-day food intake record prior to each visit. The daily energy intake and the dietary composition were calculated from subjects' dietary history records by pen and paper [22]. Sample menus that were given to subjects were shown in the additional file 1 . Women were instructed to follow a $1400 \mathrm{kcal}$ 75 -gram carbohydrate diet for four weeks. $21 \%$ of daily energy was from carbohydrate, $26 \%$ from protein and $53 \%$ from fat in the diet that was recommended to women. The analysis of the sample menu with BEBIS nutritional analysis software program (developed by Stuttgart-Hohenheim University, Stuttgart, Germany) showed that the prescribed diet for women included $52 \%$ polysaccharides, $17 \%$ disaccharides and $31 \%$ monosaccharides and 21 grams of fiber daily. The prescribed simple sugar intake constituted approximately $7 \%$ of the total energy intake. The distribution of fatty acids was as follows: $33 \%$ saturated, $17 \%$ polyunsaturated and $50 \%$ monounsaturated fatty acids. Ingested proteins were mainly of animal origin and vegetable proteins constituted approximately $22 \%$ of daily protein intake in the $1400 \mathrm{kcal} 75$-gram carbohydrate diet that was prescribed to women. Men were instructed to follow an $1800 \mathrm{kcal}$ 100 -gram carbohydrate diet for four weeks. $22 \%$ of daily energy was from carbohydrate, $29 \%$ from protein and $49 \%$ from fat in the diet that was recommended to men. The analysis of the sample menu with BEBIS nutritional analysis software program showed that the prescribed diet for men included 59\% polysaccharides, $17 \%$ disaccharides and $24 \%$ monosaccharides and 27 grams of fiber daily. The prescribed simple sugar intake constituted approximately $5 \%$ of the total energy intake. The distribution of fatty acids was as follows: $32 \%$ saturated, $20 \%$ polyunsaturated and $48 \%$ monounsaturated fatty acids. Ingested proteins were mainly of animal origin and vegetable proteins constituted approximately $19 \%$ of daily protein intake in the $1800 \mathrm{kcal} 100$-gram carbohydrate diet that was prescribed to men. Meat, chicken or fish consumption was recommended once or twice per day to all subjects (additional file 1). As following a lowcarbohydrate diet is expensive, subjects were given food products like salami, sausages, nuts and cheese to prevent noncompliance. Subjects were counseled to select from different food items at each visit. None of the participants consumed pork because pork is religiously forbidden in Islam and is not available on the Turkish market.

\section{Statistical methods}

Before- and after-diet clinical and laboratory variables were compared. There was no control group. Last observation was carried forward for subjects who did not come to their last scheduled visit and for data that the investigators failed to collect or record. Results at week-2 were carried forward to week-4 for subjects who attended only to the baseline and week- 2 visits. Subjects who attended to only baseline visit were excluded from data analysis. Categorical variables were presented as frequencies and percentages. Baseline social characteristics of men and women were compared with a $\chi^{2}$ test. When there were any expected frequencies less than five, the rest of the categories were collapsed. Fisher's exact test was employed instead of $\chi^{2}$ test when the expected frequencies were still less than five after collapsing the rest of the categories. Before- and after-diet results for continuous variables were presented as median, $25^{\text {th }}$ and $75^{\text {th }}$ percentile and were compared with a Wilcoxon signed ranks test. Before- and after-diet categorical variables were compared with a McNemar's test. The correlations between the change in energy intake, the change in carbohydrate intake or the change in insulin sensitivity and the change in outcome variables were found by calculating Pearson product-moment correlation coefficient or Spearman's rank correlation coefficient, as appropriate. The relation between starting weight and weight loss was estimated by Spearman's rank correlation coefficient. The Statistical Package for Social Sciences software, version 17.0 (SPSS Inc., Chicago, IL, USA) was used for statistical analyses.

\section{Results}

There are 43 subjects, 18 men and 25 women in this study. Initially 50 subjects, 22 men and 28 women agreed to participate. Seven subjects (four men and three women) came only to the basal screening and did not follow the diet at all. Therefore, they were excluded from the analysis. Three subjects (one man and two women) came only to the baseline and week-2 visits and their results were carried forward to week-4. Eighty percent of (40 out of 50) subjects were compliant with the prescribed diet and attended to all three visits. Six men and six women were married to each other. The mean age of men was 38 and standard deviation (SD) was seven years. The mean age of women was 39 and SD was seven years. Social characteristics of the subjects were given in Table 1. Men were more educated than women. There were no differences in smoking, alcohol drinking and physical activity habits between men and women. Twelve men $(67 \%)$ were overweight and six men (33\%) were obese. Ten women $(40 \%)$ were overweight and 15 women $(60 \%)$ were obese $\left(\chi^{2}=2.978\right.$, $\mathrm{p}=0.084$ between men and women). Energy content and macronutrient composition before and after the diet were shown in Table 2. The median of men's baseline energy intake was $1901 \mathrm{kcal}$ and was slightly higher 
Table 1 Social characteristics and life-style habits of subjects

\begin{tabular}{llll}
\hline Parameter & $\begin{array}{l}\text { Men } \\
(\mathbf{n = 1 8 )}\end{array}$ & $\begin{array}{l}\text { Women } \\
(\mathbf{n}=\mathbf{2 5})\end{array}$ & p value \\
\hline Education & & & \\
Less than 6 years of education & $39 \%(7)$ & $72 \%(18)$ & 0.030 \\
$\begin{array}{l}\text { Between } 6 \text { and 11 years of education* } \\
\text { More than 12 years of education* }\end{array}$ & $39 \%(4)$ & $20 \%(5)$ & 1.000 \\
Smoking & & $8 \%(2)$ & 0.023 \\
Never-smoker & $44 \%(8)$ & $52 \%(13)$ & 0.625 \\
Ex-smoker* & $22 \%(4)$ & $4 \%(1)$ & 0.144 \\
Current-smoker & $33 \%(6)$ & $44 \%(11)$ & 0.480 \\
Alcohol drinking & & & \\
Non-drinker* & $72 \%(13)$ & $84 \%(21)$ & 0.455 \\
Drinker* & $28 \%(5)$ & $16 \%(4)$ & 0.455 \\
Exercise & & & \\
None to less than 1 hour/week & $67 \%(12)$ & $64 \%(16)$ & 0.856 \\
Between 1-4 hour/week* & $22 \%(4)$ & $20 \%(5)$ & 1.000 \\
More than 4 hour/week* & $11 \%(2)$ & $16 \%(4)$ & 1.000 \\
\hline
\end{tabular}

Non-drinker: subject does not consume any alcoholic beverage at all Drinker: consumes less than one glass of alcoholic beverage or more per week Percentage and frequency are given and $\chi^{2}$ test is used to compare groups in unmarked rows *percentage and frequency are given and Fisher's exact test is used to compare groups

than the energy value of the prescribed diet $(1800 \mathrm{kcal})$. Compared to baseline, men achieved around $600 \mathrm{kcal}$ energy deficit with the low-carbohydrate diet. There was a significant reduction in percent energy from carbohydrate and a significant increase in percent energy from protein and fat in men. Men's individual data for daily energy intake was illustrated in Figure 1. Men's individual data for daily carbohydrate intake was illustrated in Figure 2. Eighty-nine percent of men (16/18) had an energy intake below the target level of $1800 \mathrm{kcal}$ at the end of the study. Only $39 \%$ of men (7/18) were able to achieve the target carbohydrate intake of 100 grams or less per day. The median of women's baseline energy intake was $1463 \mathrm{kcal}$ and was close to the energy value of the prescribed diet $(1400 \mathrm{kcal})$. Women had an insignificant $220 \mathrm{kcal}$ energy deficit with the prescribed lowcarbohydrate diet. There was a significant reduction in percent energy from carbohydrate and a significant increase in percent energy from fat in women. Percent energy from protein did not change significantly before and after the diet in women. Women's individual data for daily energy intake was illustrated in Figure 1. Women's individual data for daily carbohydrate intake was illustrated in Figure 2. Eighty-three percent of women $(19 / 23)$ had an energy intake below the target level of $1400 \mathrm{kcal}$ at the end of the study. Only $22 \%$ of women $(5 / 23)$ were able to achieve the target carbohydrate intake of 75 grams or less per day.

As shown in Table 3 and Table 4, after four weeks of an energy-restricted low-carbohydrate diet, all subjects had significant reductions in body weight, BMI, waist circumference, body fat ratio, systolic blood pressure, and total cholesterol, triglyceride and insulin levels, TC/ HDL-C ratio and HOMA value compared to baseline. There was a significant increase in median HDL-C levels in men, but not in women. The increase in HDL-C level

Table 2 Dietary energy and composition before and after four weeks of an energy-restricted low-carbohydrate diet in overweight or obese subjects with low HDL-C levels

\begin{tabular}{lccc}
\hline & Before-diet* & After-diet* & p valuet \\
\hline Men $(\mathrm{n}=18) \neq$ & & & \\
Energy intake (kcal/day) & $1901(1598,2479)$ & $1307(1000,1619)$ & 0.001 \\
CHO intake (\%) & $55(48,61)$ & $33(28,42)$ & $<0.001$ \\
CHO intake (gram/day) & $271(214,312)$ & $111(93,126)$ & $<0.001$ \\
Protein intake (\%) & $14(13,16)$ & $22(19,26)$ & $<0.001$ \\
Protein intake (gram/day) & $63(54,99)$ & $74(54,85)$ & 0.619 \\
Fat intake (\%) & $32(27,33)$ & $45(37,47)$ & 0.001 \\
Fat intake (gram/day) & $71(51,85)$ & $65(44,80)$ & 0.407 \\
Women ( $=23) \S$ & & & \\
Energy intake (kcal/day) & $1463(1132,1852)$ & $1243(1012,1313)$ & 0.052 \\
CHO intake (\%) & $53(45,58)$ & $30(28,39)$ & $<0.001$ \\
CHO intake (gram/day) & $192(125,220)$ & $92(80,114)$ & $<0.001$ \\
Protein intake (\%) & $14(12,16)$ & $18(16,21)$ & 0.109 \\
Protein intake (gram/day) & $53(41,69)$ & 0.627 \\
Fat intake (\%) & $50(33,63)$ & $48(43,55)$ & $<0.001$ \\
Fat intake (gram/day) & $31(26,36)$ & $68(45,79)$ & 0.005 \\
\hline
\end{tabular}

CHO: carbohydrate ${ }^{*}$ median $\left(25^{\text {th }}, 75^{\text {th }}\right.$ percentile) are given in the column tbefore- and after-diet results are compared with a Wilcoxon signed ranks test $\neq$ men were prescribed an 1800 kcal 100-gram carbohydrate diet for four weeks §women were prescribed a 1400 kcal 75-gram carbohydrate diet for four weeks Daily macronutrient intake is given as percent energy from macronutrient in upper rows and as amount of macronutrient in grams in lower rows in lines illustrating macronutrient intake. 


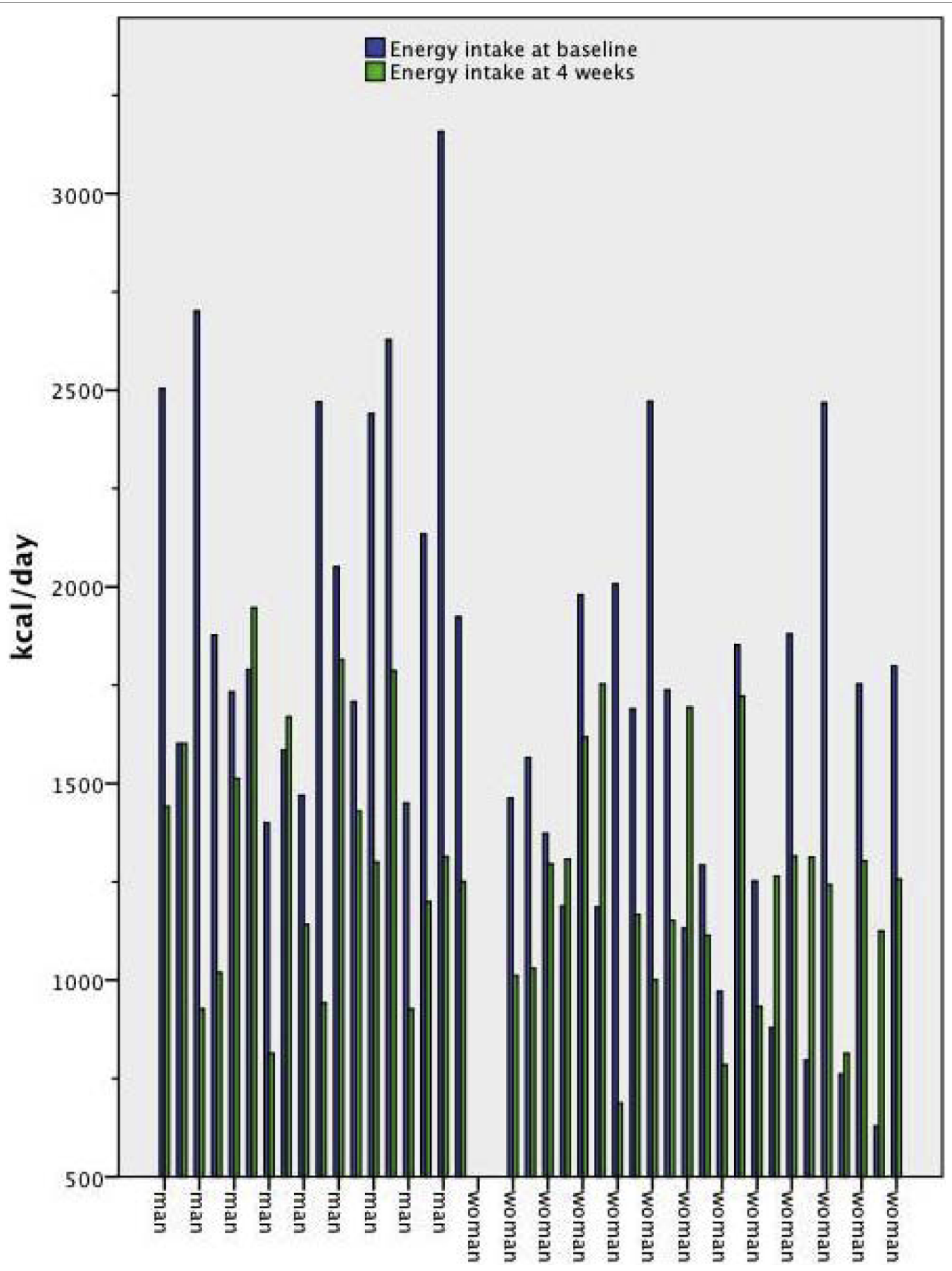

Figure 1 Individual data of daily energy intake before and after low-carbohydrate diet. Energy intake from food records before and after four weeks of an $1800 \mathrm{kcal}$ 100-gram carbohydrate diet in overweight or obese men with low HDL-C levels and before and after four weeks of a $1400 \mathrm{kcal} 75$-gram carbohydrate diet in overweight or obese women with low HDL-C levels. 


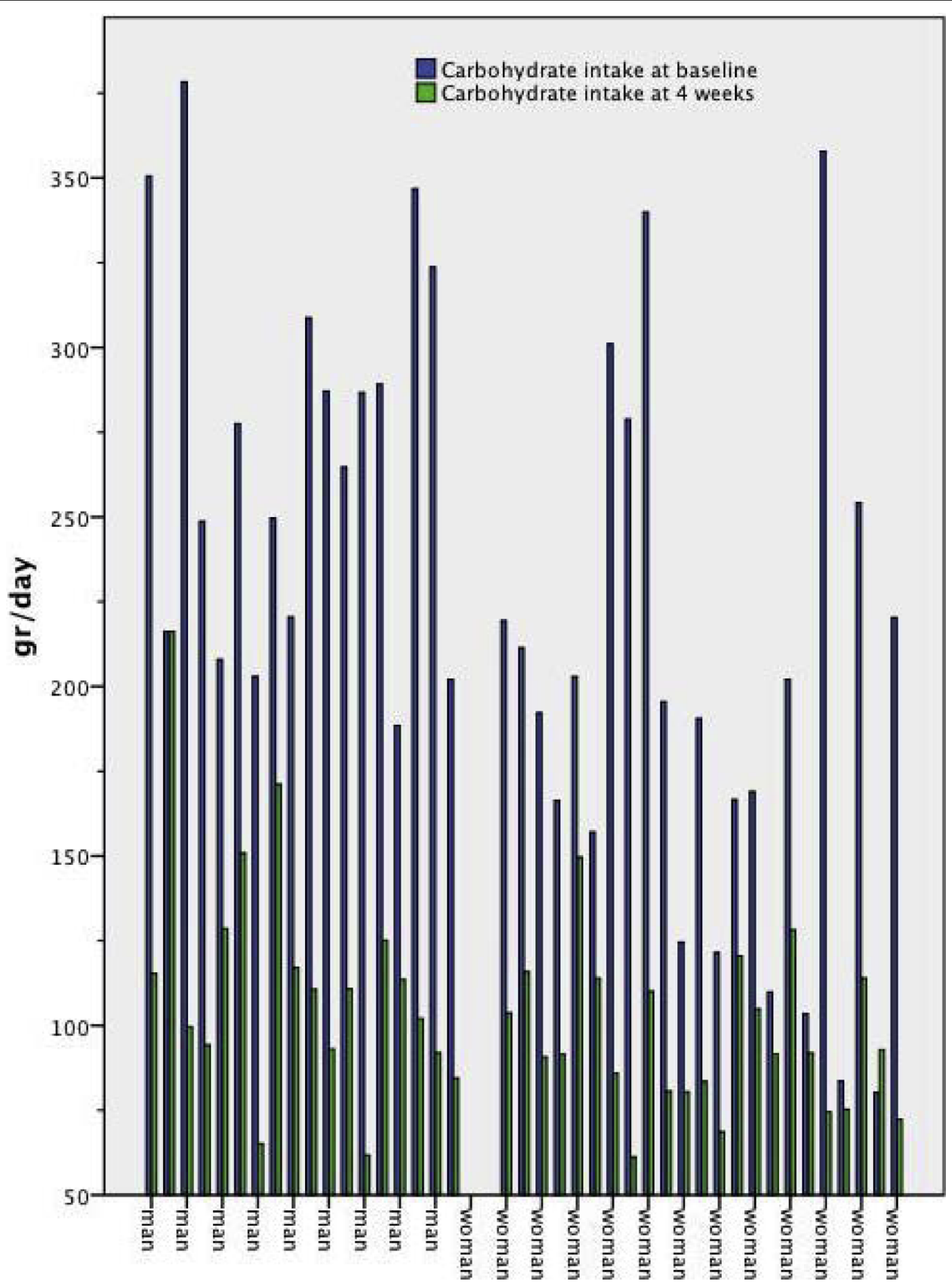

Figure 2 Individual data of daily carbohydrate intake before and after low-carbohydrate diet. Carbohydrate intake from food records before and after four weeks of an $1800 \mathrm{kcal}$ 100-gram carbohydrate diet in overweight or obese men with low HDL-C levels and before and after four weeks of a $1400 \mathrm{kcal} 75$-gram carbohydrate diet in overweight or obese women with low HDL-C levels. 
Table 3 Anthropometric indices, bioimpedance analysis, blood pressure and laboratory variables before and after four weeks of an $1800 \mathrm{kcal} 100$-gram carbohydrate diet in overweight or obese men with low HDL-C levels

\begin{tabular}{|c|c|c|c|c|}
\hline & $\mathrm{n}^{*}$ & Before-diet $†$ & After-diet $\dagger$ & $p$ value $\neq$ \\
\hline Body weight (kg) & 18 & $87.7(82.9,96.8)$ & $83.0(80.5,90.3)$ & $<0.001$ \\
\hline $\mathrm{BMI}\left(\mathrm{kg} / \mathrm{m}^{2}\right)$ & 18 & $29.1(28.2,30.6)$ & $27.9(26.8,28.9)$ & $<0.001$ \\
\hline WC (cm) & 16 & $104.8(101.0,108.1)$ & $99.3(95.4,104.1)$ & $<0.001$ \\
\hline Body fat ratio (\%) & 17 & $25.4(23.0,27.7)$ & $23.4(20.2,26.4)$ & 0.010 \\
\hline Fat mass (kg) & 17 & $22.0(19.8,24.9)$ & $20.8(16.6,22.6)$ & $<0.001$ \\
\hline $\mathrm{SBP}(\mathrm{mmHg})$ & 17 & $130(123,140)$ & $124(119,134)$ & 0.003 \\
\hline $\mathrm{DBP}(\mathrm{mmHg})$ & 17 & $76(73,91)$ & $80(71,84)$ & 0.297 \\
\hline $\mathrm{TC}(\mathrm{mmol} / \mathrm{l})$ & 18 & $4.34(4.13,5.29)$ & $4.20(3.76,4.95)$ & 0.029 \\
\hline $\mathrm{HDL}-\mathrm{C}(\mathrm{mmol} / \mathrm{l})$ & 18 & $0.83(0.74,0.88)$ & $0.96(0.82,1.03)$ & $<0.001$ \\
\hline $\mathrm{TC} / \mathrm{HDL}-\mathrm{C}$ & 18 & $5.56(4.50,7.28)$ & $4.47(3.91,5.20)$ & $<0.001$ \\
\hline LDL-C (mmol/l) & 18 & $3.11(2.54,3.76)$ & $2.80(2.32,3.56)$ & 0.058 \\
\hline $\mathrm{TG}(\mathrm{mmol} / \mathrm{l})$ & 18 & $1.23(0.85,1.85)$ & $0.95(0.63,1.27)$ & 0.004 \\
\hline Glucose $(\mathrm{mmol} / \mathrm{l})$ & 18 & $4.94(4.64,5.13)$ & $4.88(4.66,5.12)$ & 0.983 \\
\hline Insulin (pmol/l) & 17 & $80.3(59.3,98.3)$ & $61.2(45.5,81.4)$ & 0.005 \\
\hline HOMA & 17 & $2.47(1.74,3.32)$ & $1.89(1.31,2.63)$ & 0.003 \\
\hline
\end{tabular}

BMI: body mass index, WC: waist circumference, SBP: systolic blood pressure, DBP: diastolic blood pressure, TC: total cholesterol, HDL-C: high density lipoprotein cholesterol, LDL-C: low density lipoprotein cholesterol, TG: triglycerides, HOMA: homeostasis model assessment of insulin resistance *some data are missing for some of the variables tmedian $\left(25^{\text {th }}, 75^{\text {th }}\right.$ percentile) are given in the column ¥before- and after-diet results are compared with a Wilcoxon signed ranks test
Table 5 The frequency of the metabolic syndrome and its components before and after four weeks of an energyrestricted low-carbohydrate diet in overweight or obese subjects with low HDL-C levels

\begin{tabular}{|c|c|c|c|c|}
\hline & $\mathrm{n}^{*}$ & $\begin{array}{l}\text { Before- } \\
\text { diet } †\end{array}$ & $\begin{array}{l}\text { After- } \\
\text { diet† }\end{array}$ & $\underset{\text { valuef }}{\mathbf{p}}$ \\
\hline \multicolumn{5}{|l|}{$\overline{M e n \S}$} \\
\hline Metabolic Syndrome\| & 16 & $50 \%$ & $17 \%$ & 0.031 \\
\hline $\begin{array}{l}\text { Abnormal waist circumference } \\
\text { criterion }\end{array}$ & 16 & $56 \%$ & $33 \%$ & 0.125 \\
\hline Abnormal glucose criterion & 18 & $11 \%$ & $6 \%$ & 1.000 \\
\hline Abnormal triglyceride criterion & 18 & $33 \%$ & $6 \%$ & 0.063 \\
\hline Abnormal HDL-C criterion & 18 & $100 \%$ & $61 \%$ & 0.016 \\
\hline $\begin{array}{l}\text { Abnormal blood pressure } \\
\text { criterion }\end{array}$ & 17 & $53 \%$ & $33 \%$ & 0.250 \\
\hline \multicolumn{5}{|l|}{ Women } \\
\hline Metabolic Syndrome\| & 25 & $48 \%$ & $24 \%$ & 0.070 \\
\hline $\begin{array}{l}\text { Abnormal waist circumference } \\
\text { criterion }\end{array}$ & 25 & $76 \%$ & $60 \%$ & 0.125 \\
\hline Abnormal glucose criterion & 25 & $16 \%$ & $28 \%$ & 0.250 \\
\hline Abnormal triglyceride criterion & 25 & $16 \%$ & $4 \%$ & 0.250 \\
\hline Abnormal HDL-C criterion & 25 & $100 \%$ & $88 \%$ & 0.250 \\
\hline $\begin{array}{l}\text { Abnormal blood pressure } \\
\text { criterion }\end{array}$ & 25 & $40 \%$ & $24 \%$ & 0.219 \\
\hline
\end{tabular}

*some data are missing for some of the variables tpercentage is given in the column $\neq$ before- and after-diet frequencies are compared with a McNemar's test §men were prescribed an $1800 \mathrm{kcal} 100$-gram ( $22 \%$ of daily energy from) carbohydrate diet $\|$ the metabolic syndrome and its components are defined according to modified United States National Cholesterol Education Program Adult Treatment Panel III criteria $[1,20]$ Iwomen were prescribed a $1400 \mathrm{kcal}$ 75 -gram ( $21 \%$ of daily energy from) carbohydrate diet

Table 4 Anthropometric indices, bioimpedance analysis, blood pressure and laboratory variables before and after four weeks of a $1400 \mathrm{kcal}$ 75-gram carbohydrate diet in overweight or obese women with low HDL-C levels

\begin{tabular}{|c|c|c|c|c|}
\hline & $\mathrm{n}^{*}$ & Before-diet $†$ & After-diet $†$ & $p$ valuef \\
\hline Body weight (kg) & 25 & $73.2(68.5,81.7)$ & $70.8(65.5,79.1)$ & $<0.001$ \\
\hline BMI $\left(\mathrm{kg} / \mathrm{m}^{2}\right)$ & 25 & $30.4(28.0,32.9)$ & $29.5(27.2,31.4)$ & $<0.001$ \\
\hline WC $(\mathrm{cm})$ & 25 & $95.0(87.5,99.0)$ & $92.0(86.0,96.5)$ & 0.002 \\
\hline Body fat ratio (\%) & 24 & $38.0(34.6,39.7)$ & $34.6(32.7,39.6)$ & $<0.001$ \\
\hline Fat mass (kg) & 24 & $27.7(23.4,31.7)$ & $24.3(22.1,29.9)$ & $<0.001$ \\
\hline $\mathrm{SBP}(\mathrm{mmHg})$ & 25 & $123(115,132)$ & $112(107,124)$ & 0.005 \\
\hline $\mathrm{DBP}(\mathrm{mmHg})$ & 25 & & & \\
\hline $\mathrm{TC}(\mathrm{mmol} / \mathrm{l})$ & 25 & $4.50(3.84,5.25)$ & $3.93(3.56,4.42)$ & $<0.001$ \\
\hline $\mathrm{HDL}-\mathrm{C}(\mathrm{mmol} / \mathrm{l})$ & 25 & $1.03(0.94,1.09)$ & $1.01(0.89,1.14)$ & 0.165 \\
\hline $\mathrm{TC} / \mathrm{HDL}-\mathrm{C}$ & 25 & $4.34(3.73,5.48)$ & $3.81(3.35,4.30)$ & $<0.001$ \\
\hline LDL-C (mmol/l) & 25 & $3.00(2.37,3.59)$ & $2.46(2.13,2.93)$ & $<0.001$ \\
\hline $\mathrm{TG}(\mathrm{mmol} / \mathrm{l})$ & 25 & $1.12(0.89,1.58)$ & $0.82(0.73,1.12)$ & 0.011 \\
\hline Glucose $(\mathrm{mmol} / \mathrm{l})$ & 25 & $5.11(4.91,5.41)$ & $5.11(4.83,5.55)$ & 0.742 \\
\hline Insulin (pmol/l) & 23 & $61.0(46.6,96.4)$ & $56.0(38.0,92.6)$ & 0.005 \\
\hline HOMA & 23 & $2.01(1.44,2.92)$ & $1.71(1.24,2.74)$ & 0.006 \\
\hline
\end{tabular}

BMI: body mass index, WC: waist circumference, SBP: systolic blood pressure, DBP: diastolic blood pressure, TC: total cholesterol, HDL-C: high density lipoprotein cholesterol, LDL-C: low density lipoprotein cholesterol, TG: triglycerides, HOMA: homeostasis model assessment of insulin resistance *some data are missing for some of the variables tmedian $\left(25^{\text {th }}, 75^{\text {th }}\right.$ percentile) are given in the column fbefore- and after-diet results are compared with a Wilcoxon signed ranks test was accompanied by a $\sim 600$ kcal daily energy deficit and a $-4.7 \mathrm{~kg}$ difference in median body weight in men. After four weeks of a low-carbohydrate diet, there was no significant change in HDL-C levels in women. This was accompanied by an insignificant $220 \mathrm{kcal}$ daily energy deficit but a significant $-2.4 \mathrm{~kg}$ difference in median body weight in women. The frequency of the metabolic syndrome and abnormal HDL-C component significantly improved only in men and the frequency of the metabolic syndrome tended to improve in women (Table 5). The scatter plot of the change in daily energy intake versus the change in HDL-C level was presented in Figure 3. The scatter plot of the change in daily carbohydrate intake versus the change in HDL-C level was presented in Figure 4. The correlation coefficients between the change in energy intake, the change in carbohydrate intake or the change in insulin sensitivity and the change in outcome variables were weak (Table 6). The change in daily energy intake was significantly correlated with the change in triglycerides in men. The change in daily carbohydrate intake was significantly correlated with the change in body weight, total cholesterol/HDL-C ratio and triglycerides in the whole group. The change in daily carbohydrate intake was 


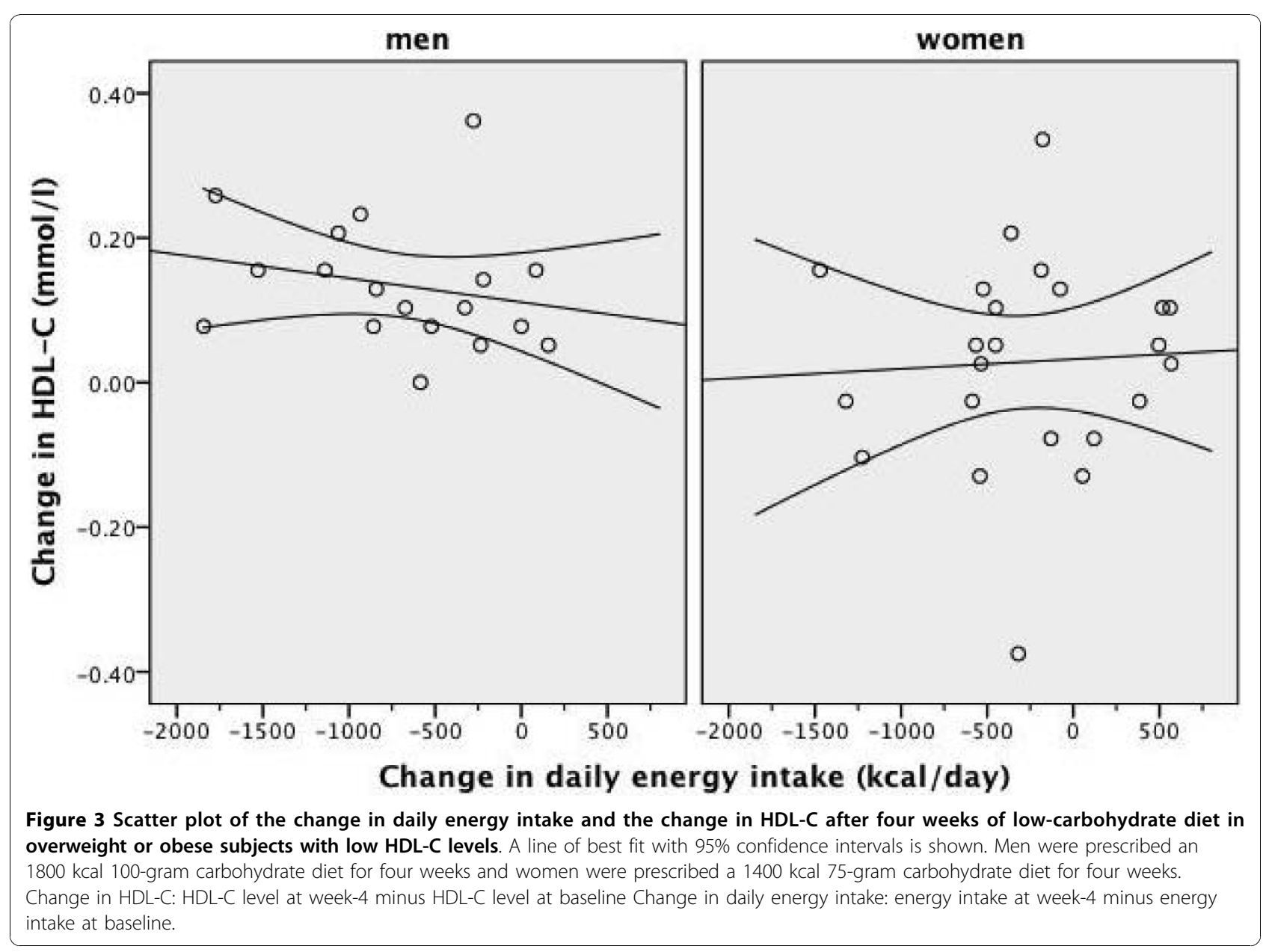

significantly correlated with the change in body weight, BMI, total cholesterol/HDL-C ratio and triglycerides in men and with the change in diastolic blood pressure, insulin levels and HOMA in women. There were more instances in which the change in carbohydrate intake was significantly correlated with outcome variables than the change in energy intake (Table 6). The correlation between baseline weight and weight loss was not significant, Spearman's rho $=-0.186, \mathrm{p}=0.460$ in men and Spearman's rho $=0.014, \mathrm{p}=0.948$ in women. The starting weight and final weight were highly correlated (Spearman's rho $=0.983, \mathrm{p}<0.001$ for men and Spearman's rho $=0.987, \mathrm{p}<0.001$ for women). The relation between the baseline weight and the final weight was shown in Figure 5. The scatter plot of the change in daily energy intake versus weight loss was presented in Figure 6. The scatter plot of the change in daily energy intake from carbohydrate versus weight loss was presented in Figure 7 . The scatter plot of the change in daily carbohydrate intake versus weight loss was presented in Figure 8.

\section{Discussion}

Beneficial effects of low-carbohydrate diets have been observed before. These studies were on normal weight normolipidemic subjects $[17,18]$, overweight or obese subjects [13-16,23-25], subjects with hypertension $[14,26]$, metabolic syndrome $[14,16,26,27]$, hyperlipidemia $[13,15]$ or diabetes $[16,27,28]$. Our study evaluates the effects of a low-carbohydrate diet in subjects with low HDL-C levels. Compared to North American or European populations, Turks have low levels of total cholesterol and HDL-C and relative roles of the metabolic syndrome and atherogenic dyslipidemia are more pronounced [29]. The mean and SD of HDL-C levels of Turkish men are 37 and $12 \mathrm{mg} / \mathrm{dl}$, respectively. The mean and SD of HDL-C levels of Turkish women are 45 and $13 \mathrm{mg} / \mathrm{dl}$, respectively [30]. Molecular genetic studies showed that single nucleotide polymorphisms in hepatic lipase, cholesterol ester transfer protein and ATP binding cassette transporter A1 genes are associated with plasma HDL-C levels in the Turkish population [31-34]. A previous study showed that $61 \%$ of adult 


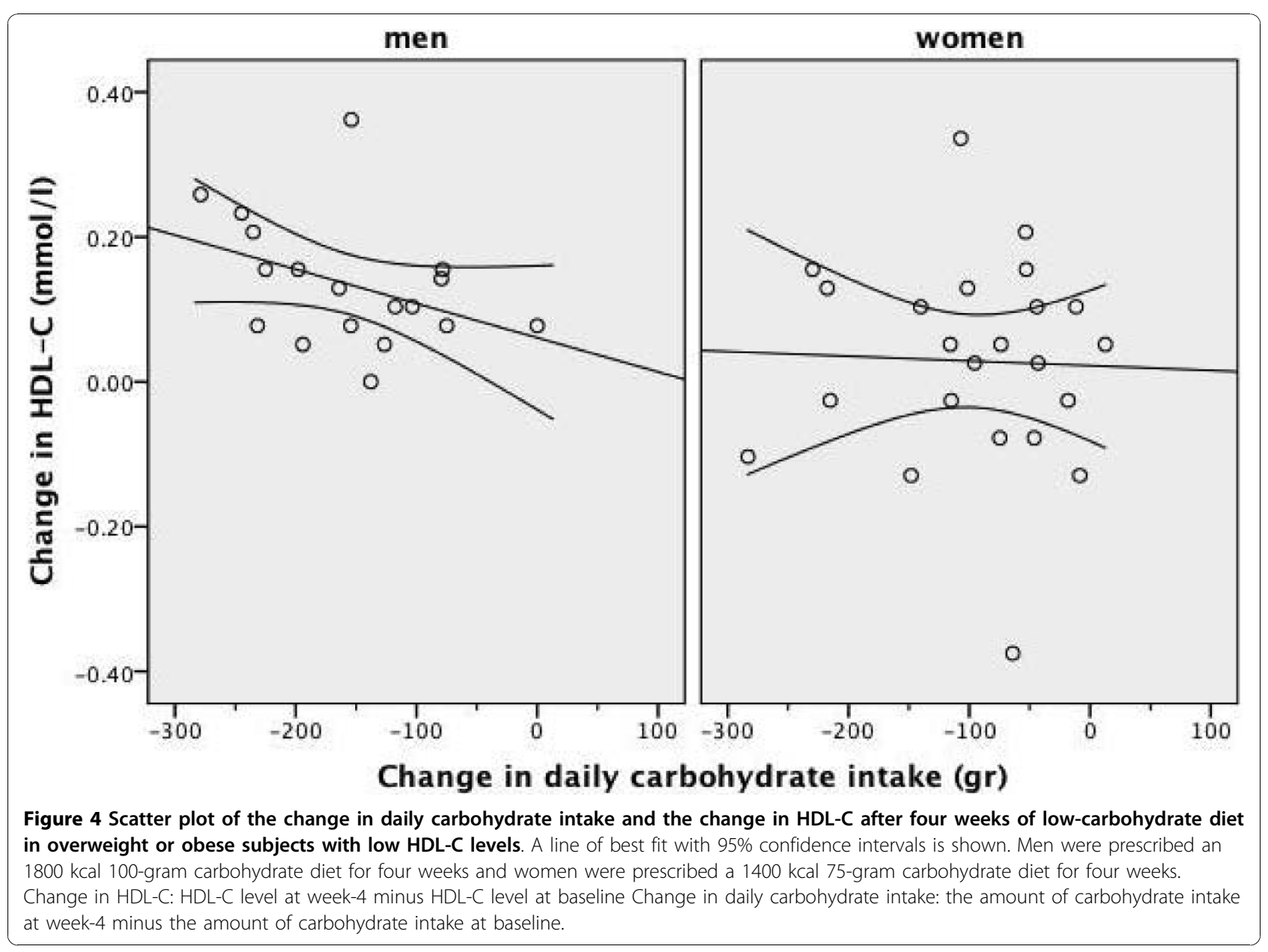

nondiabetic Turkish population had low HDL-C levels ( $<40 \mathrm{mg} / \mathrm{dl}$ for men and $<50 \mathrm{mg} / \mathrm{dl}$ for women) [35]. Therefore, we think that the effects of dietary therapy should be investigated in subjects with low HDL-C levels, especially in a population with a high prevalence of low HDL-C levels. Al-Sarraj and coworkers showed that a carbohydrate-restricted diet improves insulin resistance and all features of the metabolic syndrome except for the low HDL-C component in Emirati adults [36]. The authors commented that genetic predisposition to low HDL-C might explain the lack of effect of the low-carbohydrate diet on HDL-C levels [36]. Similarly, genetic factors have been found to be associated with low HDL-C levels in the Turkish population [31-34]. In contrast to the above-mentioned study in Emirati adults, a low-carbohydrate diet with energy restriction raised HDL-C levels in men in our study. As there are discrepant results among dietary intervention studies, further studies are needed in subjects with low HDL-C levels.

It has been reported that carbohydrate intake is related to HDL-C levels and every 100 gram/day increment of carbohydrate intake is associated with a $5.8 \mathrm{mg} / \mathrm{dl}(0.15 \mathrm{mmol} / \mathrm{L})$ decrease in HDL-C levels after adjustment of confounders in a multivariate nutrient residual model [37]. A low-carbohydrate diet is effective in improving glycemic control and reducing hemoglobi$\mathrm{nA}_{1 \mathrm{c}}$ levels in subjects with diabetes mellitus [28]. Volek and Feinman proposed that the metabolic syndrome should be defined as an entity that favorably responds to carbohydrate restriction because a low-carbohydrate diet effectively targets each component of the metabolic syndrome: central obesity, low HDL-C, high triglycerides, high blood pressure and high blood glucose $[10,11]$. The mechanism of improvement is thought to be secondary to reduction of insulin resistance. Volek et al. stressed that dietary carbohydrate intake is a key element in disposal of excess dietary fat intake, directly or indirectly through the secretion of insulin [38]. Dietary carbohydrate modulates lipolysis, de novo lipogenesis and effects the interaction between dietary fat intake and plasma saturated fatty acid levels. Volek et al. showed that when carbohydrate intake was low and consequently plasma glucose and insulin levels were 
Table 6 The correlation coefficients between the change in daily energy intake, the change in daily carbohydrate intake or the change in insulin sensitivity and outcome variables before and after four weeks of lowcarbohydrate diet in overweight or obese subjects with low HDL-C levels

$\Delta$ Energy intake $\triangle$ CHO intake $\triangle$ HOMA

All subjectst

$\triangle B M l \quad 0.121$

$\triangle W C \quad 0.132$

$\Delta$ body fat ratio $\quad-0.182$

$\Delta$ fat mass $\quad-0.120$

$\triangle \mathrm{SBP} \quad 0.082$

$\triangle \mathrm{DBP} \quad 0.307$

$\triangle \mathrm{TC} \quad-0.084$

$\triangle \mathrm{HDL}-\mathrm{C} \quad-0.172$

$\triangle \mathrm{TC} / \mathrm{HDL}-\mathrm{C} \quad 0.134$

$\triangle \mathrm{LDL}-\mathrm{C} \quad-0.218$

$\triangle \mathrm{TG} \quad 0.303$

$\Delta$ Glucose $\quad-0.113$

$\triangle$ Insulin $\quad 0.263$

$\triangle$ HOMA $\quad 0.213$

Men $¥ \S$

$\triangle$ body weight $\quad 0.386$

$\triangle \mathrm{BMI} \quad 0.352$

$\triangle W C \quad 0.296$

$\Delta$ body fat ratio $\quad 0.088$

$\Delta$ fat mass $\quad 0.115$

$\triangle$ SBP $\quad 0.400$

$\begin{array}{ll}\triangle \mathrm{DBP} & 0.352\end{array}$

$\begin{array}{ll}\triangle \mathrm{TC} & 0.185\end{array}$

$\triangle \mathrm{HDL}-\mathrm{C} \quad-0.349$

$\triangle \mathrm{TC} / \mathrm{HDL}-\mathrm{C} \quad 0.232$

$\triangle \mathrm{LDL}-\mathrm{C} \quad-0.098$

$\triangle \mathrm{TG}$

$\Delta$ Glucose

$0.601^{* *}$

$-0.209$

$\triangle$ Insulin

$\triangle \mathrm{HOMA}$

Women $\neq \|$

$\triangle$ body weight

$\triangle \mathrm{BMl}$

$\triangle W C$

$\Delta$ body fat ratio

$\triangle$ fat mass

$\triangle \mathrm{SBP}$

$\triangle \mathrm{DBP}$

$\triangle \mathrm{TC}$

$\triangle \mathrm{HDL}-\mathrm{C}$

$\triangle \mathrm{TC} / \mathrm{HDL}-\mathrm{C}$

$\triangle \mathrm{LDL}-\mathrm{C}$

$\triangle \mathrm{TG}$

$\Delta$ Glucose

$\Delta$ Insulin

\section{$0.321^{*}$}

0.183

0.142

$-0.189$

0.103

0.126

0.285

$-0.033$

$-0.266$

$0.319^{*}$

$-0.214$

$0.427^{* *}$

$-0.84$

0.220

0.162

$0.493 *$

$0.482^{*}$

0.385

0.211

0.303

0.475

0.126

0.375

$-0.421$

$0.552^{*}$

0.001

$0.677^{* *}$

$-0.319$

$-0.189$

$-0.174$

0.001

$-0.050$

$-0.146$

$-0.179$

$-0.131$

0.200

$0.442^{*}$

$-0.038$

$-0.063$

0.036

$-0.137$

0.260

0.072

$0.449^{*}$
$-0.085$

$-0.133$

$-0.144$

0.168

0.131

$-0.060$

0.139

$-0.030$

$-0.059$

0.033

$-0.051$

0.059

$0.589^{* *}$

$0.981^{* *}$

1

$-0.530^{*}$

$-0.569^{*}$

$-0.300$

0.414

0.072

0.039

0.196

0.012

0.093

$-0.130$

0.002

0.118

0.384

$0.966^{* *}$

1

0.160

0.148

$-0.186$

0.115

0.180

0.064

0.085

0.067

$-0.036$

0.081

0.083

0.106

$0.614^{* *}$

$0.975^{* *}$
Table 6 The correlation coefficients between the change in daily energy intake, the change in daily carbohydrate intake or the change in insulin sensitivity and outcome variables before and after four weeks of low-carbohydrate diet in overweight or obese subjects with low HDLC levels (Continued)

\begin{tabular}{|c|c|c|}
\hline & $0.435^{*}$ & \\
\hline \multicolumn{3}{|c|}{ 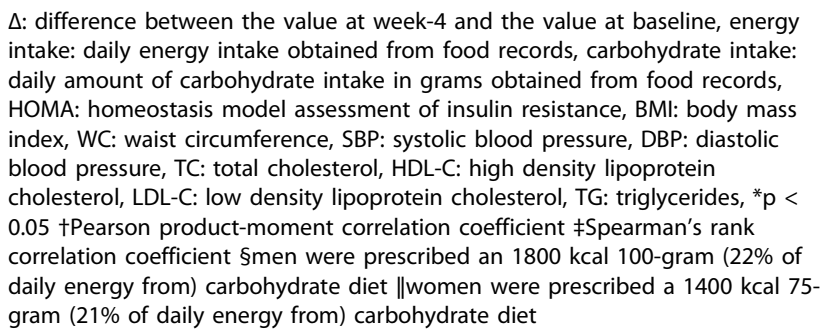 } \\
\hline
\end{tabular}

lower, a higher saturated fat intake would cause a reduction in relative proportions of circulating saturated fatty acids in triglyceride and cholesterol ester fractions [39]. In addition to improving classical cardiovascular risk factors, compared to a low-fat diet, a low-carbohydrate diet favorably effects nonclassical cardiovascular risk factors like apo B, apo A-I, apo B/apo A-I ratio, LDL particle size and distribution [39], postprandial lipemia and postprandial vascular endothelial function as assessed by flow-mediated dilatation [40]. Carbohydrate restriction also exerts an anti-inflammatory effect with a decrease in proinflammatory cytokine tumor necrosis factor- $\alpha$, the chemokines interleukin- 8 and monocyte chemotactic protein-1, the adhesion molecules E-selectin and intracellular adhesion molecule-1 and antifibrinolytic substance plasminogen-activator inhibitor-1 [41]. In summary, a large body of evidence indicates that abnormal fatty acid status and inflammatory state that are characteristics of the metabolic syndrome are better improved by a low-carbohydrate diet than a low-fat diet [38-41]. Low-carbohydrate diets have different favorable effects on CVD risk factors than low-fat diets $[15,16]$. Meckling and coworkers proposed that a low-fat diet should be initiated when reduction of blood cholesterol is the primary goal and a low-carbohydrate diet should be initiated when reduction of insulin resistance is the primary goal [13]. In view of our findings, we suggest that an energy-restricted low-carbohydrate diet should be initiated when an increase in HDL-C level is the primary goal.

\section{Limitations of the study}

Even if some low-carbohydrate food items were provided free of charge, the vast majority of subjects could not achieve the target carbohydrate intake in our study. In contrast, most subjects reached their goal in caloric restriction. As low-carbohydrate food items are expensive, 

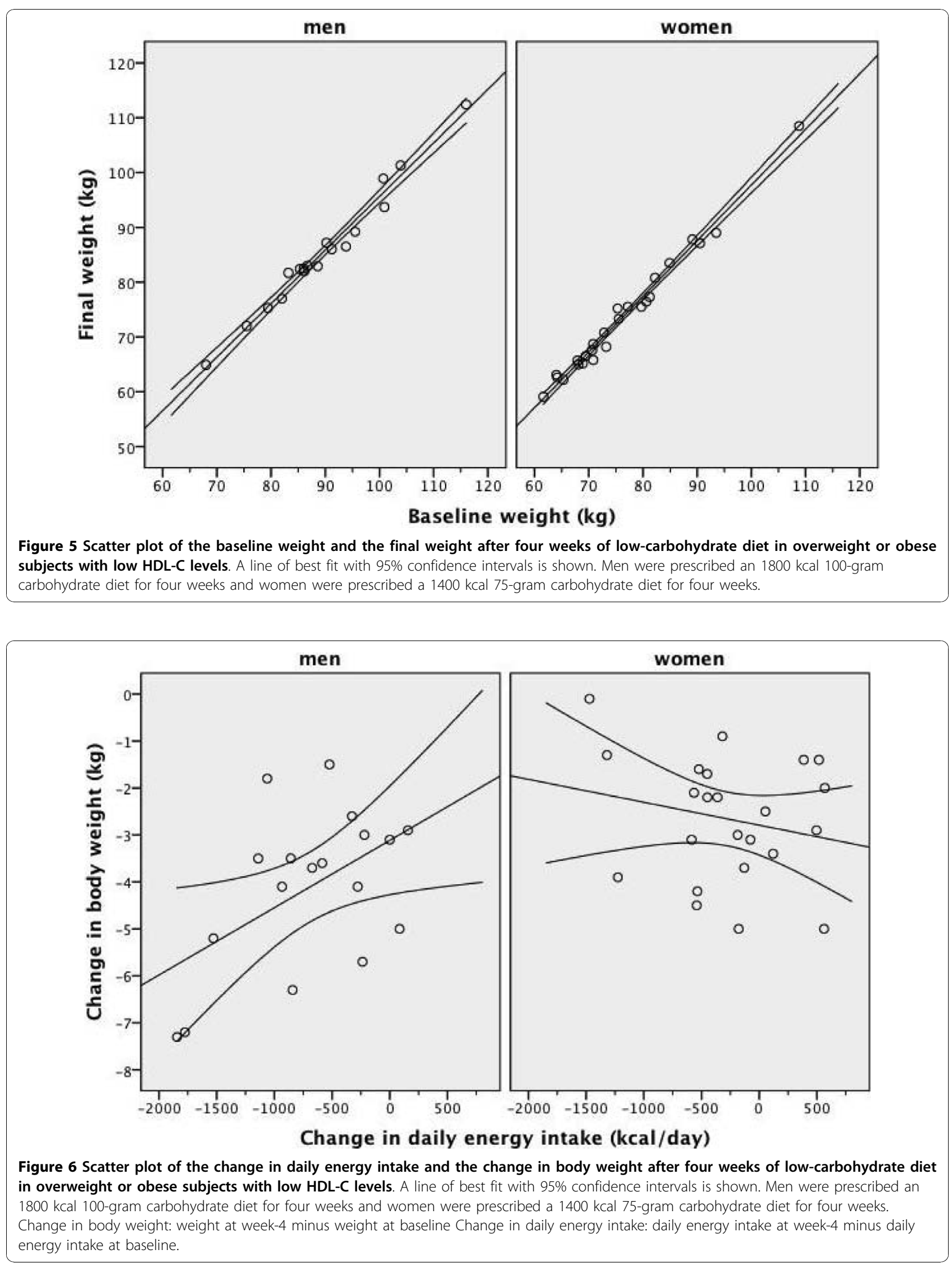

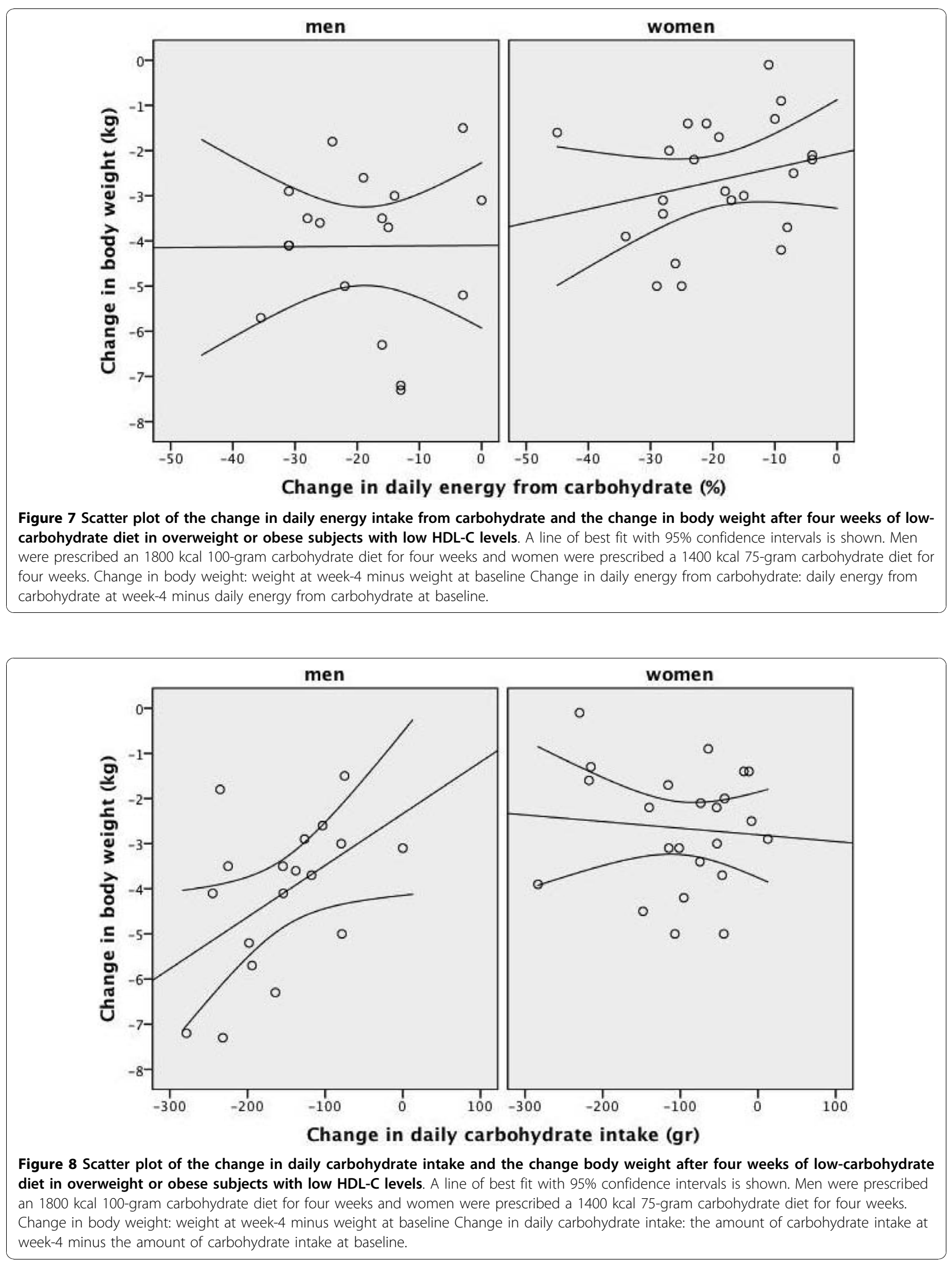
it may be difficult to follow a low-carbohydrate diet for the long-term in a developing country, like Turkey. Another limitation is that subjects were invited from a previous epidemiological study, not from the general population. The beneficial outcomes observed in this study were obtained with both energy and carbohydrate restriction. The results of this study should be viewed as pilot data that warrant further research. A long-term study with a control group is needed to validate our results. Studies that prescribe carbohydrate restriction with ad libitum energy intake show an increase in HDL-C levels with the dietary intervention [15,42-46], but there are few studies that show no significant change in HDL-C levels with ad libitum lowcarbohydrate diets $[16,27]$. Studies that restricted both carbohydrate and energy intake showed a variable response in HDL-C levels as well. Recent selected dietary intervention studies that were published after 2002 and restricted carbohydrates to less than $40 \%$ of daily energy intake are summarized in Table 7. Male to female ratio, duration, the degree of energy and carbohydrate restriction, dietary composition and the amount of weight loss are highly variable in these studies. A consistent effect of a low-carbohydrate diet is a reduction of triglyceride levels. As seen in Table 7, studies of low-carbohydrate diets in which subjects lost greater amount of weight are consistently associated with an elevation of HDL-C levels whereas studies with smaller weight reduction are mostly associated with no significant change in HDL-C levels. Except for our study, none of the studies in Table 7 enrolled subjects only with low HDL-C levels. Frisch and coworkers showed no effect of a low-carbohydrate diet on HDL-C levels, although carbohydrate restriction was only $40 \%$ of daily energy intake in that study [12]. As seen in Table 7, only few studies showed an elevation of LDL-C levels with lowcarbohydrate diets. We also did not observe an elevation of LDL-C level with a low-carbohydrate diet in our study. Carbohydrate restriction causes elevations in HDL-C levels from increased reverse cholesterol transport. The increase in HDL-C levels from carbohydrate restriction is characterized by an increase in HDL particle size but not quantity and an increase in lecithin:cholesterol acyltransferase activity with no change in cholesterol ester transfer protein activity [47].

\section{Conclusions}

A short term energy-restricted low-carbohydrate diet causes weight loss, fat loss, a decrease in total cholesterol and triglyceride levels and an improvement in insulin resistance in overweight and obese subjects with low HDL-C levels. HDL-C levels increased significantly with energy restriction, carbohydrate restriction and weight loss in men. HDL-C levels did not change in women in whom there was no significant energy restriction but a significant carbohydrate restriction and a relatively small but significant amount of weight loss. Differences in gender, baseline characteristics of subjects

Table 7 Results from recent selected studies* that evaluated the effects of low-carbohydrate diets

\begin{tabular}{|c|c|c|c|c|c|c|c|c|c|c|}
\hline Author Year & $n$ & $\begin{array}{c}\text { Basal BMI }(\mathrm{kg} / \\
\left.\mathrm{m}^{2}\right)\end{array}$ & $\begin{array}{l}\text { Duration } \\
\text { (week) }\end{array}$ & $\begin{array}{c}\Delta \text { Energy (kcal/ } \\
\text { day) }\end{array}$ & $\begin{array}{c}\text { Dietary } \\
\text { composition }\end{array}$ & $\begin{array}{c}\Delta \text { weight } \\
\text { (kg) }\end{array}$ & $\begin{array}{l}\text { HDL- } \\
\text { C }\end{array}$ & TG & $\begin{array}{l}\text { LDL- } \\
\text { C }\end{array}$ & Reference \\
\hline Sharman 2002 & $12 \mathrm{~m}$ & $\mathrm{BMI}<25$ & 6 & None & $8 / 30 / 61$ & -2.2 & $\leftrightarrow$ & $\downarrow$ & $\leftrightarrow$ & {$[18]$} \\
\hline Volek 2003 & $10 w$ & $\mathrm{BMI}<25$ & 4 & None & $10 / 29 / 60$ & -1.8 & $\uparrow$ & $\downarrow$ & $\uparrow$ & {$[17]$} \\
\hline Volek 2004 & $13 w$ & $\mathrm{BMI} \geq 25$ & 4 & -643 & $9 / 28 / 63$ & -3.0 & $\leftrightarrow$ & $\leftrightarrow$ & $\leftrightarrow$ & {$[25]$} \\
\hline Sharman 2004 & $15 \mathrm{~m}$ & $\mathrm{BMI} \geq 25$ & 6 & -738 & $8 / 28 / 63$ & -6.1 & $\leftrightarrow$ & $\downarrow$ & $\leftrightarrow$ & {$[24]$} \\
\hline $\begin{array}{l}\text { Meckling } \\
2004\end{array}$ & $\begin{array}{c}5 \mathrm{~m} / 10 \\
\mathrm{w}\end{array}$ & $B M I \geq 25$ & 10 & -763 & $16 / 26 / 56$ & -7.0 & $\uparrow$ & $\downarrow$ & $\leftrightarrow$ & [13] \\
\hline Noakes 2006 & $\begin{array}{c}4 \mathrm{~m} / 20 \\
w\end{array}$ & $\mathrm{BMI}>28$ & 12 & -615 & $25 / 30 / 50$ & -8.0 & $\uparrow$ & $\downarrow$ & $\uparrow$ & {$[48]$} \\
\hline $\begin{array}{l}\text { Westman } \\
2008+\end{array}$ & $\begin{array}{c}7 \mathrm{~m} / 14 \\
\mathrm{w}\end{array}$ & $\mathrm{BMI}>27$ & 24 & -578 & $13 / 28 / 59$ & -11.1 & $\uparrow$ & $\downarrow$ & $\leftrightarrow$ & {$[28]$} \\
\hline $\begin{array}{l}\text { Brinkworth } \\
2009\end{array}$ & $\begin{array}{c}11 \mathrm{~m} / 24 \\
\mathrm{w}\end{array}$ & Abd obesity & 52 & -500 & $4 / 35 / 61$ & -14.5 & $\uparrow$ & $\downarrow$ & $\uparrow$ & {$[49]$} \\
\hline Jenkins 2009ł & $\begin{array}{c}10 \mathrm{~m} / 15 \\
\mathrm{w}\end{array}$ & $\mathrm{BMI}>27$ & 4 & -328 & $28 / 30 / 43$ & -3.9 & $\leftrightarrow$ & $\downarrow$ & $\downarrow$ & {$[50]$} \\
\hline Volek 2009 & $\begin{array}{c}10 \mathrm{~m} / 10 \\
\mathrm{w}\end{array}$ & $\mathrm{BMI}>25$ & 12 & -847 & $13 / 28 / 59$ & -10.1 & $\uparrow$ & $\downarrow$ & $\leftrightarrow$ & [39] \\
\hline Can 2010 & $18 \mathrm{~m}$ & $\mathrm{BMI} \geq 25$ & 4 & -600 & $33 / 22 / 45$ & -3.7 & $\uparrow$ & $\downarrow$ & $\leftrightarrow$ & $\mathrm{T}$ \\
\hline Can 2010 & $25 w$ & $\mathrm{BMI} \geq 25$ & 4 & -220 & $30 / 18 / 48$ & -1.1 & $\leftrightarrow$ & $\downarrow$ & $\downarrow$ & $\mathrm{T}$ \\
\hline
\end{tabular}

BMI: body mass index, $\Delta$ Energy: difference between end-study and baseline mean or median daily energy intake, Dietary composition: percentage of daily energy from carbohydrate/protein/fat, $\Delta$ weight: difference between mean or median end-study and baseline weight, HDL-C: high density lipoprotein cholesterol, TG: triglycerides, LDL-C: low density lipoprotein cholesterol, m: men, w: women, Abd obesity: abdominal obesity, T: this study. *selected studies published after 2002 and restricted carbohydrate intake to less than $40 \%$ of daily energy intake are included in the table. A summary of studies published prior to 2004 can be found in the review by Volek and Feinman [10]. Studies of low-carbohydrate diets based on ad libitum energy intake, glycemic index or glycemic load are excluded from the table. tonly subjects with diabetes mellitus were enrolled into the study fprotein and fat are from plant origin in the study 
and the dietary intervention may account for divergent outcomes in HDL-C levels between men and women. The results of this study suggest that both energy and carbohydrate restriction should be considered in overweight and obese subjects with low HDL-C levels, especially when LDL-C levels are not elevated.

\section{Additional material}

Additional file 1: Sample menus. Sample menus for an $1800 \mathrm{kcal} 100-$ gram carbohydrate diet and a $1400 \mathrm{kcal}$ 75-gram carbohydrate diet.

\begin{abstract}
Abbreviations
Abd obesity: abdominal obesity; BMI: body mass index; CVD: cardiovascular disease; DBP: diastolic blood pressure; HDL-C: high density lipoprotein cholesterol; HOMA: homeostasis model assessment of insulin resistance; LDLC: Iow density lipoprotein cholesterol; m: men; NCEP: The United States National Cholesterol Education Program Adult Treatment Panel III; SBP: systolic blood pressure; SD: standard deviation; T: this study; TC: total cholesterol; TG: triglycerides; w: women; WC: waist circumference.

\section{Acknowledgements}

We thank to Robert W. Mahley, MD, PhD from the Gladstone Institute of Cardiovascular Disease, San Francisco, CA, USA for his support for the study. We thank to Sibel Tanır and Guy M. Pepin from the Istanbul Office of Gladstone Institute of Cardiovascular Disease for helping in subject recruitment and blood drawing. We also thank to Mithat Gönen, PhD from Memorial Sloan-Kettering Cancer Center, New York, NY, USA for statistical guidance. Canan Uysal and Ahmet Selçuk Can presented part of the data as a poster at the 6th International Nutrition and Dietetic Congress in Antalya, Turkey between April 2nd and 6th 2008.
\end{abstract}

\section{Author details}

'Department of Medicine, Kadir Has University, Faculty of Medicine, Vefa Bey Sokak, No: 5, 34349, Gayrettepe, Beşiktaş, Istanbul, Turkey. ${ }^{2}$ Medical Nutrition Center, Sezai Selek Sokak, No: 14/11, Nişantaşı, Şişli, Istanbul, Turkey. ${ }^{3}$ Department of Biochemistry, Vehbi Koç Foundation American Hospital, Güzelbahçe Sokak, No: 20, Nişantaşı, Şişli, Istanbul, Turkey.

\section{Authors' contributions \\ ASC planned the study, obtained Ethics Committee approval, performed medical examinations and wrote the manuscript. CU obtained anthropometric indices, evaluated dietary intake records and gave the dietary instructions to subjects. KEP measured laboratory variables. All authors read and approved the final manuscript.}

\section{Competing interests}

The authors declare that they have no competing interests.

Received: 8 April 2010 Accepted: 9 November 2010

Published: 9 November 2010

\section{References}

1. Executive Summary of The Third Report of The National Cholesterol Education Program (NCEP) Expert Panel on Detection, Evaluation, And Treatment of High Blood Cholesterol In Adults (Adult Treatment Panel III). Jama 2001, 285:2486-2497.

2. deGoma EM, Leeper NJ, Heidenreich PA: Clinical significance of highdensity lipoprotein cholesterol in patients with low low-density lipoprotein cholesterol. J Am Coll Cardiol 2008, 51:49-55.

3. Grover SA, Kaouache M, Joseph L, Barter P, Davignon J: Evaluating the incremental benefits of raising high-density lipoprotein cholesterol levels during lipid therapy after adjustment for the reductions in other blood lipid levels. Arch Intern Med 2009, 169:1775-1780.
4. Katcher HI, Hill AM, Lanford JL, Yoo JS, Kris-Etherton PM: Lifestyle approaches and dietary strategies to lower LDL-cholesterol and triglycerides and raise HDL-cholesterol. Endocrinol Metab Clin North Am 2009, 38:45-78.

5. Perez-Lopez FR, Chedraui P, Haya J, Cuadros JL: Effects of the Mediterranean diet on longevity and age-related morbid conditions. Maturitas 2009, 64:67-79.

6. Rumawas ME, Meigs JB, Dwyer JT, McKeown NM, Jacques PF: Mediterranean-style dietary pattern, reduced risk of metabolic syndrome traits, and incidence in the Framingham Offspring Cohort. Am $J$ Clin Nutr 2009, 90:1608-1614.

7. Decewicz DJ, Neatrour DM, Burke A, Haberkorn MJ, Patney HL, Vernalis MN, Ellsworth DL: Effects of cardiovascular lifestyle change on lipoprotein subclass profiles defined by nuclear magnetic resonance spectroscopy. Lipids Health Dis 2009, 8:26.

8. Lichtenstein AH, Appel $L$, Brands M, Carnethon M, Daniels S, Franch HA, Franklin B, Kris-Etherton P, Harris WS, Howard B, et al: Diet and lifestyle recommendations revision 2006: a scientific statement from the American Heart Association Nutrition Committee. Circulation 2006, 114:82-96.

9. WHO: Obesity: preventing and managing the global epidemic. Report of a WHO consultation on obesity. World Health Organization Technical Report Series WHO/NUT/NCD/981 Geneva: WHO; 1997.

10. Volek JS, Feinman RD: Carbohydrate restriction improves the features of Metabolic Syndrome. Metabolic Syndrome may be defined by the response to carbohydrate restriction. Nutr Metab (Lond) 2005, 2:31.

11. Feinman RD, Volek JS: Carbohydrate restriction as the default treatment for type 2 diabetes and metabolic syndrome. Scand Cardiovasc J 2008, 42:256-263.

12. Frisch S, Zittermann A, Berthold HK, Gotting C, Kuhn J, Kleesiek K, Stehle P, Kortke $H$ : A randomized controlled trial on the efficacy of carbohydratereduced or fat-reduced diets in patients attending a telemedically guided weight loss program. Cardiovasc Diabetol 2009, 8:36.

13. Meckling KA, O'Sullivan C, Saari D: Comparison of a low-fat diet to a lowcarbohydrate diet on weight loss, body composition, and risk factors for diabetes and cardiovascular disease in free-living, overweight men and women. J Clin Endocrinol Metab 2004, 89:2717-2723.

14. Tay J, Brinkworth GD, Noakes M, Keogh J, Clifton PM: Metabolic effects of weight loss on a very-low-carbohydrate diet compared with an isocaloric high-carbohydrate diet in abdominally obese subjects. J Am Coll Cardiol 2008, 51:59-67.

15. Yancy WS Jr, Olsen MK, Guyton JR, Bakst RP, Westman EC: A lowcarbohydrate, ketogenic diet versus a low-fat diet to treat obesity and hyperlipidemia: a randomized, controlled trial. Ann Intern Med 2004, 140:769-777.

16. Stern L, lqbal N, Seshadri P, Chicano KL, Daily DA, McGrory J, Williams M, Gracely EJ, Samaha FF: The effects of low-carbohydrate versus conventional weight loss diets in severely obese adults: one-year followup of a randomized trial. Ann Intern Med 2004, 140:778-785.

17. Volek JS, Sharman MJ, Gomez AL, Scheett TP, Kraemer WJ: An isoenergetic very low carbohydrate diet improves serum HDL cholesterol and triacylglycerol concentrations, the total cholesterol to $\mathrm{HDL}$ cholesterol ratio and postprandial lipemic responses compared with a low fat diet in normal weight, normolipidemic women. J Nutr 2003, 133:2756-2761.

18. Sharman MJ, Kraemer WJ, Love DM, Avery NG, Gomez AL, Scheett TP, Volek JS: A ketogenic diet favorably affects serum biomarkers for cardiovascular disease in normal-weight men. J Nutr 2002, 132:1879-1885.

19. Mahley RW, Can S, Ozbayrakci S, Bersot TP, Tanir S, Palaoglu KE, Pepin GM: Modulation of high-density lipoproteins in a population in Istanbul, Turkey, with low levels of high-density lipoproteins. Am J Cardiol 2005, 96:547-555.

20. Grundy SM, Cleeman JI, Daniels SR, Donato KA, Eckel RH, Franklin BA, Gordon DJ, Krauss RM, Savage PJ, Smith SC Jr, et al: Diagnosis and management of the metabolic syndrome: an American Heart Association/National Heart, Lung, and Blood Institute Scientific Statement. Circulation 2005, 112:2735-2752.

21. Matthews DR, Hosker JP, Rudenski AS, Naylor BA, Treacher DF, Turner RC: Homeostasis model assessment: insulin resistance and beta-cell function from fasting plasma glucose and insulin concentrations in man. Diabetologia 1985, 28:412-419. 
22. Food Exchange List. [http://www.nhlbi.nih.gov/health/public/heart/obesity/ lose_wt/fd_exch.htm].

23. Sacks FM, Bray GA, Carey VJ, Smith SR, Ryan DH, Anton SD, McManus K, Champagne CM, Bishop LM, Laranjo N, et al: Comparison of weight-loss diets with different compositions of fat, protein, and carbohydrates. N Engl J Med 2009, 360:859-873.

24. Sharman MJ, Gomez AL, Kraemer WJ, Volek JS: Very low-carbohydrate and low-fat diets affect fasting lipids and postprandial lipemia differently in overweight men. J Nutr 2004, 134:880-885.

25. Volek JS, Sharman MJ, Gomez AL, DiPasquale C, Roti M, Pumerantz A, Kraemer WJ: Comparison of a very low-carbohydrate and low-fat diet on fasting lipids, LDL subclasses, insulin resistance, and postprandial lipemic responses in overweight women. J Am Coll Nutr 2004, 23:177-184.

26. Muzio F, Mondazzi L, Harris WS, Sommariva D, Branchi A: Effects of moderate variations in the macronutrient content of the diet on cardiovascular disease risk factors in obese patients with the metabolic syndrome. Am J Clin Nutr 2007, 86:946-951.

27. Seshadri P, Iqbal N, Stern L, Williams M, Chicano KL, Daily DA, McGrory J, Gracely EJ, Rader DJ, Samaha FF: A randomized study comparing the effects of a low-carbohydrate diet and a conventional diet on lipoprotein subfractions and C-reactive protein levels in patients with severe obesity. Am J Med 2004, 117:398-405.

28. Westman EC, Yancy WS Jr, Mavropoulos JC, Marquart M, McDuffie JR: The effect of a low-carbohydrate, ketogenic diet versus a low-glycemic index diet on glycemic control in type 2 diabetes mellitus. Nutr Metab (Lond) 2008, 5:36.

29. Onat A, Ceyhan K, Basar O, Erer B, Toprak S, Sansoy V: Metabolic syndrome: major impact on coronary risk in a population with low cholesterol levels-a prospective and cross-sectional evaluation. Atherosclerosis 2002, 165:285-292.

30. Onat A: Risk factors and cardiovascular disease in Turkey. Atherosclerosis 2001, 156:1-10.

31. Ozsait B, Komurcu Bayrak E, Poda M, Can G, Hergenc G, Onat A, Humphries SE, Erginel Unaltuna N: CETP TaqIB polymorphism in Turkish adults: association with dyslipidemia and metabolic syndrome. Anadolu Kardiyol Derg 2008, 8:324-330

32. Hodoglugil U, Williamson DW, Mahley RW: Polymorphisms in the hepatic lipase gene affect plasma HDL-cholesterol levels in a Turkish population. J Lipid Res 2010, 51:422-430.

33. Dogru-Abbasoglu S, Parildar-Karpuzoglu H, Depboylu B, Cine N, Uysal M, Aykac-Toker G: $1405 \mathrm{~V}$ and TaqlB polymorphisms of the cholesteryl ester transfer protein and their relation to serum lipid and lipoprotein levels in a Turkish population. Cell Biochem Funct 2009, 27:76-80.

34. Hodoglugil U, Williamson DW, Huang Y, Mahley RW: Common polymorphisms of ATP binding cassette transporter A1, including a functional promoter polymorphism, associated with plasma high density lipoprotein cholesterol levels in Turks. Atherosclerosis 2005, 183:199-212.

35. Can AS, Bersot TP: Analysis of agreement among definitions of metabolic syndrome in nondiabetic Turkish adults: a methodological study. BMC Public Health 2007, 7:353.

36. Al-Sarraj T, Saadi H, Calle MC, Volek JS, Fernandez ML: Carbohydrate restriction, as a first-line dietary intervention, effectively reduces biomarkers of metabolic syndrome in Emirati adults. J Nutr 2009, 139:1667-1676.

37. Merchant AT, Anand SS, Kelemen LE, Vuksan V, Jacobs R, Davis B, Teo K, Yusuf S: Carbohydrate intake and HDL in a multiethnic population. Am J Clin Nutr 2007, 85:225-230.

38. Volek JS, Fernandez ML, Feinman RD, Phinney SD: Dietary carbohydrate restriction induces a unique metabolic state positively affecting atherogenic dyslipidemia, fatty acid partitioning, and metabolic syndrome. Prog Lipid Res 2008, 47:307-318.

39. Volek JS, Phinney SD, Forsythe CE, Quann EE, Wood RJ, Puglisi MJ, Kraemer WJ, Bibus DM, Fernandez ML, Feinman RD: Carbohydrate restriction has a more favorable impact on the metabolic syndrome than a low fat diet. Lipids 2009, 44:297-309.

40. Volek JS, Ballard KD, Silvestre R, Judelson DA, Quann EE, Forsythe CE, Fernandez ML, Kraemer WJ: Effects of dietary carbohydrate restriction versus low-fat diet on flow-mediated dilation. Metabolism 2009, 58:1769-1777.

41. Forsythe CE, Phinney SD, Fernandez ML, Quann EE, Wood RJ, Bibus DM, Kraemer WJ, Feinman RD, Volek JS: Comparison of low fat and low carbohydrate diets on circulating fatty acid composition and markers of inflammation. Lipids 2008, 43:65-77.

42. McAuley KA, Hopkins CM, Smith KJ, McLay RT, Williams SM, Taylor RW, Mann Jl: Comparison of high-fat and high-protein diets with a highcarbohydrate diet in insulin-resistant obese women. Diabetologia 2005, 48:8-16.

43. Dansinger ML, Gleason JA, Griffith JL, Selker HP, Schaefer EJ: Comparison of the Atkins, Ornish, Weight Watchers, and Zone diets for weight loss and heart disease risk reduction: a randomized trial. Jama 2005, 293:43-53.

44. Brehm BJ, Seeley RJ, Daniels SR, D'Alessio DA: A randomized trial comparing a very low carbohydrate diet and a calorie-restricted low fat diet on body weight and cardiovascular risk factors in healthy women. $J$ Clin Endocrinol Metab 2003, 88:1617-1623.

45. Gardner CD, Kiazand A, Alhassan S, Kim S, Stafford RS, Balise RR, Kraemer HC, King AC: Comparison of the Atkins, Zone, Ornish, and LEARN diets for change in weight and related risk factors among overweight premenopausal women: the A TO Z Weight Loss Study: a randomized trial. Jama 2007, 297:969-977.

46. Foster GD, Wyatt HR, Hill JO, McGuckin BG, Brill C, Mohammed BS, Szapary PO, Rader DJ, Edman JS, Klein S: A randomized trial of a lowcarbohydrate diet for obesity. N Engl J Med 2003, 348:2082-2090.

47. Wood RJ: Effect of dietary carbohydrate restriction with and without weight loss on atherogenic dyslipidemia. Nutr Rev 2006, 64:539-545.

48. Noakes M, Foster PR, Keogh JB, James AP, Mamo JC, Clifton PM: Comparison of isocaloric very low carbohydrate/high saturated fat and high carbohydrate/low saturated fat diets on body composition and cardiovascular risk. Nutr Metab (Lond) 2006, 3:7.

49. Brinkworth GD, Noakes M, Buckley JD, Keogh JB, Clifton PM: Long-term effects of a very-low-carbohydrate weight loss diet compared with an isocaloric low-fat diet after 12 mo. Am J Clin Nutr 2009, 90:23-32.

50. Jenkins DJ, Wong JM, Kendall CW, Esfahani A, Ng WW, Leong TC, Faulkner DA, Vidgen E, Greaves KA, Paul G, Singer W: The effect of a plantbased low-carbohydrate ("Eco-Atkins") diet on body weight and blood lipid concentrations in hyperlipidemic subjects. Arch Intern Med 2009, 169:1046-1054.

\section{Pre-publication history}

The pre-publication history for this paper can be accessed here: http://www.biomedcentral.com/1472-6823/10/18/prepub

doi:10.1186/1472-6823-10-18

Cite this article as: Can et al:: Short term effects of a low-carbohydrate diet in overweight and obese subjects with low HDL-C levels. BMC Endocrine Disorders 2010 10:18.

\section{Submit your next manuscript to BioMed Central and take full advantage of:}

- Convenient online submission

- Thorough peer review

- No space constraints or color figure charges

- Immediate publication on acceptance

- Inclusion in PubMed, CAS, Scopus and Google Scholar

- Research which is freely available for redistribution 